\title{
Peel colour, anthocyanin, TSS content and sensory evaluation of some common fruits: A comparative study
}

\author{
Mohammad Moneruzzaman Khandaker*1 ${ }^{1}$, Fatin Nor Amirah ${ }^{1}$, Ali Majrashi ${ }^{2}$, Mohammad Hailmi Sajili ${ }^{1}$, Khamsah \\ Suryati Mohd ${ }^{1}$, and Nashriyah Mat ${ }^{1}$
}

${ }^{1}$ School of Agriculture Science \& Biotechnology, Faculty of Bioresources and Food Industry, Universiti Sultan Zainal Abidin, Besut Campus, 22200 Besut, Terengganu, Malaysia

${ }^{2}$ Department of Biological Science, Faculty of Science, Taif University, Taif, Saudi Arabia

*Corresponding author: moneruzzaman@unisza.edu.my

\section{Abstract}

The study was conducted to identify the best eating quality of some common fruits in the Malaysian local market. The selected market fruits such as papaya, mango, banana, wax apple (jambu madu) and tomato were collected from local markets located in Besut, Terengganu, Malaysia at different ripening stages. The qualities of these fruits were determined by the peel colour analysis, juice, total soluble solids, anthocyanin and total flavonoid content at different ripening stages. Furthermore, sensory evaluation was tested to find out the consumer preferences of fruit at different ripening stages by giving score to the attributes. The $\mathrm{L}^{*}$ and $\mathrm{a}^{*}$ values and hue angle showed significant differences between ripening stages of all fruits. Meanwhile, there was no significant difference between ripening stages of tomato for $b^{*}$ value and also of mango, wax apple and tomato for Chroma value. As for juice content, the highest value was shown in papaya with significant differences. On the other hand, the highest TSS content was shown in banana with significant differences. Anthocyanin content was found to be the highest in banana as compared to other fruits, with significant differences. Meanwhile, flavonoid content was the highest in banana with significant differences. Sensory evaluation indicated that banana has the highest score compared to other fruits. Juice, TSS and anthocyanin content were correlated with each other and ripen fruits contain the better peel colour. This study showed that mango and banana were the two best fruit to be consumed as it has the best quality, with the best stage to consume was at the ripen stage.

Keywords: Peel color, Anthocyanin, TSS, Sensory evaluation, Fruits.

Abbreviations: TSS_total soluble solids, $L_{-}$lightness, a_ greenness to redness, b_blueness to yellowness, TFC_total flavonoid content, $R_{-}$ correlation coefficient, SD_ standard deviation, ${ }^{* *}$ _significant at $1 \%$ level, ${ }^{*}$ _significant at $5 \%$ level, $Q E_{-}$quercetin equivalents, ${ }^{\circ}{ }^{\circ}$ hue angle.

\section{Introduction}

Fruit quality has become a subject of an increasing consciousness among consumers during fruit selection at the local market. The term quality is related to the degree of excellence and absence of defect of a fresh fruit, which implies to the sensory attributes (appearance, colour, texture, flavor, and aroma), nutrient (energy, carbohydrates, and fiber), and functional properties (vitamins and minerals). According to Kamol et al. (2014), fruits harvested at different maturity stages exhibit significance variation in the fruit quality. Moneruzzaman et al. (2008) reported that tomato fruits harvested at different maturity stages exhibit significant variation in the biochemical properties. Fruit ripening stages involve dramatic changes in colour, composition, aroma, flavour and texture. Ripening as the results of a series of degradable processes which are regulates by various hydrolytic enzymes. These include in changes in metabolism and gene expression which have a dramatic effect on fruit quality. Thus, fruit quality is affected by the maturation of fruit which exhibits different nutrient content and other phytochemical values.

Horticultural produce are easy perishable products and one of the biggest challenges of local farmers nowadays is to convince the consumers to buy their products. Fruit quality is a concept, which includes sensory, mechanical and functional properties as well as bio-chemical composition and nutritional values (Abbot, 1999). Consumer behavior of selecting fresh fruits was based on the best visual appearance by the uniformity of size, shape, and colour. The components of visual quality can also be deduced by glossiness, the absence of a defect in shape or peel, and disease free. Thus, most of the consumers are prone to look for the best visual appearance in consideration of fresh fruit selection compared to its nutritional value. On the other hand, the lack of knowledge of the nutritious principles of fruits, as well as fruits partial use due to improper eating habits causes the waste of horticulture produce. It is important to provide knowledge on choosing the best fresh fruit quality by using the peel colour assessment according to its maturation and ripening stages.

The local market fruits consist of a wide variation of seasonal and tropical fruits. This local fruit of papaya, mango, banana, wax apple and tomato are available in our local market throughout the year as they are grown locally by our farmers. The fruits can be categorized into climacteric and nonclimacteric fruits. Climacteric fruit is when the respiration rate of the fruits increases to a maximum just before full ripening occurred along with the increase of ethylene production before senescence (Sudheer and Indira, 2007). Meanwhile, nonclimacteric fruit is when the respiration rate of some fruits does 
not accelerate after the fruit has been harvested. This nonclimacteric fruit is suggested to be harvested when it had already ripened because they are not capable of continuing the ripening process once removed from the plant (Sudheer and Indira, 2007). Furthermore, this climacteric process can cause physiological changes in the fruit that include colour changes, sugar formation and phytochemical development.

The consumer would inquire about the information on quality consumption of fruits. Fruit quality differs in different ripening stages of fruits, and fruit quality can be change by some horticultural techniques (Moneruzzaman et al., 2013). Consumers however usually judge the quality of fresh fruits on the basis of colour during their purchases from markets. A small number of consumers are more concern about the nutritional quality of fresh fruits; which are excellent source of energy, vitamins, minerals, dietary fibres, and many bioactive compounds that enhance human health. Fruits supply arrays of colors, flavor, texture and bulkiness to the pleasure of eating and they are essential for the proper maintenance of human health. Fruit has long been promoted for their health benefits in preventing various cancer and age-related diseases. The information about fruit quality is scarcely determine by observing the external colour. Hence, there is no specific standard to measure the quality of local fruits. Thus, the objectives of this study were to measure the fruit peel colour and TSS content at different ripening stages of fruits, to determine the anthocyanin and flavonoid content in local market fruits, and to identify a standard for best eating quality of local markets fruits

\section{Results and discussion}

\section{Peel colour analysis}

The result of peel colour analysis of Hunter $L^{*}, a^{*}$ and $b^{*}$ values parameters, Chroma values and hue angles in papaya, mango, banana, wax apple and tomato according to ripening stages were presented in Figures $1 \& 2$ and Table 3 . The result shows that there were significant differences $(P<0.05)$ between ripening stages of all fruits for $L^{*}, a^{*}$ and hue angle. Moreover, there is significant differences $(P<0.05)$ in papaya, mango, banana and wax apple between different ripening stages for $b^{*}$ value, and for Chroma value of papaya and banana. However, there was no significant difference $(P>0.05)$ between ripening stage of tomato for $b^{*}$ value and also in mango, wax apple and tomato for Chroma value.

The $L^{*}$ value which indicates the lightness of all fruit samples at different ripening stage was determined. Banana, mango and papaya had shown a significant increase as the fruit ripened (Figure 1). The greatest luminosity (high $L^{*}$ value) had shown in banana as compared to other fruits with the highest value (73.20) at over-ripen stage. As for wax apple and tomato, along the ripening process, the fruit had a significant decrease of $L^{*}$ value. The least luminosity was found in wax apple and tomato at over-ripen stage with values of 32.70 and 40.74 , respectively. Wax apple showed least luminosity that are correlated with colour pigment, which is can be distinguished by a dense red colour of the peel, and this phenomena was supported by AyalaSilva et al. (2005) in 'Tommy Atkins' mango cultivar. Thus, the greatest luminosity can be distinguished by dense red peel colour and least luminosity can be distinguished by green peel colour.

The luminosity of fruit peel in immature fruit can have the highest value and decrease as the maturation process takes place. Lower value of luminosity can be an indicator to determine the later stage of maturity.
The $a^{*}$ or red-green value of all fruit samples at different ripening stage was determined. All fruits had a significant increase of colour components from unripe stage to the overripen stage (Figure 2). The high $a^{*}$ value in wax apple and tomato can be seen at over-ripen stage with values of 20.66 and 22.97 , respectively. Whereas, the low a* value was recorded in banana, papaya and mango at unripe stage with negative value. Negative value of a* can be distinguished by green peel colour and positive value in red peel colour of Maridol papaya at unripe stage and ripen stage as published by Basulto et al. (2009). Thus, a* value can be an indicator for ripened fruit but not for early maturity.

The $b^{*}$ or yellow-blue value of all fruit samples at different ripening stage was also determined. Papaya, mango, and banana had a significant increase of $b^{*}$ value along with ripening (Figure 2). Meanwhile, tomato had no significant difference $(P>0.05)$ between the ripening stages, which means there is no colour change because of the slow ripening process which was supported by Rosnah et al. (2012), that also indicated no significant difference $(P>0.05)$ of wax apple $b^{*}$ value during ripening. Wax apple showed slight decrease of $b^{*}$ value at the lowest value (12.91) in the over-ripen stage and the highest value (21.96) in the unripe stage. Peel colour is a good indicator to determine the maturity stage in which the $a^{*}$ value can be used to detect early maturity of fruit while $b^{*}$ value can be used to detect late maturity as reported by Basulto et al. (2009).

The chroma value of different fruit based on their ripening stage had been determined and the value was found different in different types of fruits. The results showed that chroma and hue colour space values of the fruits were significantly affected by ripening stages (Table 1). Papaya and banana gave significantly increased chrome values as the fruit ripen. Meanwhile, mango, wax apple and tomato had shown no significant difference $(P>0.05)$ which indicated the saturation of fruit peel had no change over ripening. This demonstrates that peel colour of fruits was varied with fruit types and maturity stages. It was reported that fruit peel colour also depends on variety of fruits (Al-Saif et al., 2011). Application of plant growth regulators and phloemic stress stimulate the development of colour of plant parts (Saifuddin et al, 2009). The highest saturation was found in papaya with the highest value (68.86) at ripen stage. However, the wax apple showed the lightest saturation with the lowest value (22.95) at ripens stage. The peel colour intensity was associated with ripening process as reported by Basulto et al. (2009). Besides fruit maturity and ripening process, colour of the plant parts also depends on removal of young leaves and plant growth regulators treatment (Moneruzzaman et al., 2010a)

The hue angle of local fruit samples at different ripening stages had been determined. Fruit peel showed green colour at the unripe stage with hue angle values ranging from $104.67^{\circ}$ in tomato to $122.41^{\circ}$ in papaya. The yellow peel colour of banana was developed at hue angle value of $93.46^{\circ}$ during ripen stage (Table 1). Lower hue angle value indicates the red peel colour as shown in tomato $\left(41.97^{\circ}\right)$ and wax apple $\left(52.11^{\circ}\right)$, repectively, at over-ripen stage that was supported by Ayala-Silva et al. (2005). The highest hue angle value with the dull dark green colour was recorded in unripe papaya fruits, followed by banana and wax apple, respectively (Table 1). At the colour turning stage, wax apple fruits produced a dull yellowish-red and the lowest hue angel compared to other fruits.

Tomato fruits at ripen stage produced dull light reddish-yellow colour and the lowest hue angel than other fruits. The lowest hue angle value with the dull yellow orange colour was recorded in tomato fruits. Thus, Chroma value and hue angle showed correlation to ripening of fruit. Fruit in unripe stage can be 
Table 1. Hunter parameter of chroma and hue angle of papaya, mango, banana, wax apple and tomato at different ripening stages.

\begin{tabular}{lllll}
\hline Fruit & $\begin{array}{l}\text { Ripening } \\
\text { stage }\end{array}$ & Chroma value & $\begin{array}{l}\text { Hue angle } \\
\left(\mathrm{h}^{\circ}\right)\end{array}$ & Peel colour \\
\hline Papaya & Unripe & 35.65 & 122.41 & \\
& Colour turning & 60.62 & 108.42 & Dull dark green \\
& Ripen & 68.86 & 81.99 & Vivid green \\
Mango & Over-ripen & 65.18 & 75.72 & Vivid Yellow \\
& Unripe & 40.65 & 118.98 & Vivid Yellowish red \\
& Colour turning & 47.64 & 102.26 & Vivid green \\
& Ripen & 53.15 & 93.29 & Dull light yesllowish green \\
Banana & Over-ripen & 44.86 & 99.16 & Vivid light reddish yellow \\
& Unripe & 47.31 & 119.87 & Vivid yellow \\
& Colour turning & 54.59 & 106.2 & Dull green \\
& Ripen & 63.79 & 93.46 & Vivid greenish yellow \\
Wax apple & Over-ripen & 60.55 & 90.96 & Vivid reddish yellow \\
& Unripe & 23.80 & 118.11 & Vivid yellow \\
& Colour turning & 23.65 & 57.69 & Dull green \\
& Ripen & 23.71 & 59.37 & Dull yellowish red \\
\multirow{3}{*}{ Tomato } & Over-ripen & 22.43 & 52.11 & Dull yellowish red \\
& Unripe & 27.26 & 104.67 & Dull red \\
& Colour turning & 30.20 & 11.01 & Dull light green \\
& Ripen & 37.14 & 29.55 & Dull light greenish yellow \\
& Over-ripen & 34.59 & 41.97 & Dull light reddish yellow \\
\hline
\end{tabular}

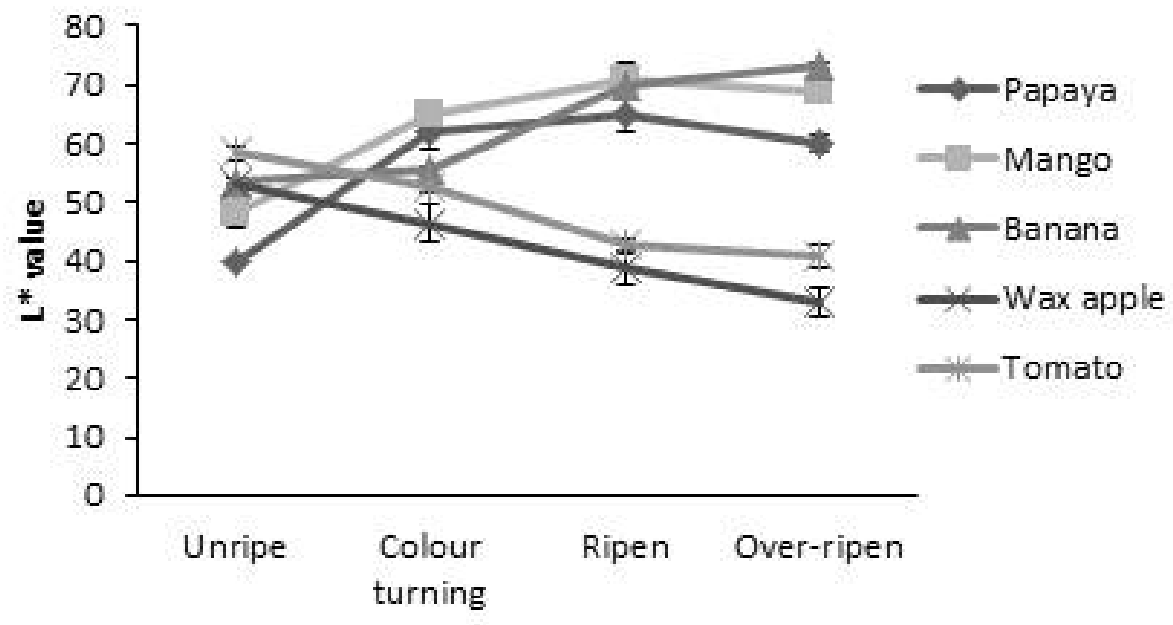

Ripening stage

Fig 1. Peel colour components $L^{*}$ value in papaya, mango, banana, wax apple and tomato collected at different ripening stages. Each point is the mean $\pm S D$ of three replicates.

Table 2. Regression equation, correlation coefficient $(r)$ and coefficients of determination $\left(R^{2}\right)$ of different parameters of fruits.

\begin{tabular}{|c|c|c|}
\hline Regression equation & $\begin{array}{c}\text { Correlation coefficient } \\
\text { (r) }\end{array}$ & Coefficients of determination (R2) \\
\hline \multicolumn{3}{|l|}{ Juice and TSS content } \\
\hline$\overline{Y(\text { Papaya })=0.0981 x+3.75}$ & $0.86^{*}$ & 0.756 \\
\hline$Y($ Mango $)=0.2045 x+2.92$ & $0.89 *$ & 0.802 \\
\hline$y($ Banana $)=0.5216 x+0.38$ & $0.97 * *$ & 0.961 \\
\hline$Y($ Wax apple $)=0.4071 x-24.32$ & $0.97^{* *}$ & 0.962 \\
\hline $\mathrm{Y}($ Tomato $)=0.0217 \mathrm{x}+2.408$ & 0.73 & 0.542 \\
\hline \multicolumn{3}{|l|}{ TSS and anthocyanin content } \\
\hline$Y($ Papaya $)=0.0009 x-0.0039$ & 0.62 & 0.396 \\
\hline$Y($ Mango $)=0.031 x-0.2944$ & $0.96 * *$ & 0.932 \\
\hline$y($ Banana $)=0.0009 x+0.393$ & $0.78^{*}$ & 0.612 \\
\hline$Y($ Wax apple $)=0.00025 x+0.1191$ & 0.21 & 0.047 \\
\hline $\mathrm{Y}($ Tomato $)=0.036 \mathrm{x}-0.073$ & $0.81 *$ & 0.664 \\
\hline
\end{tabular}


a
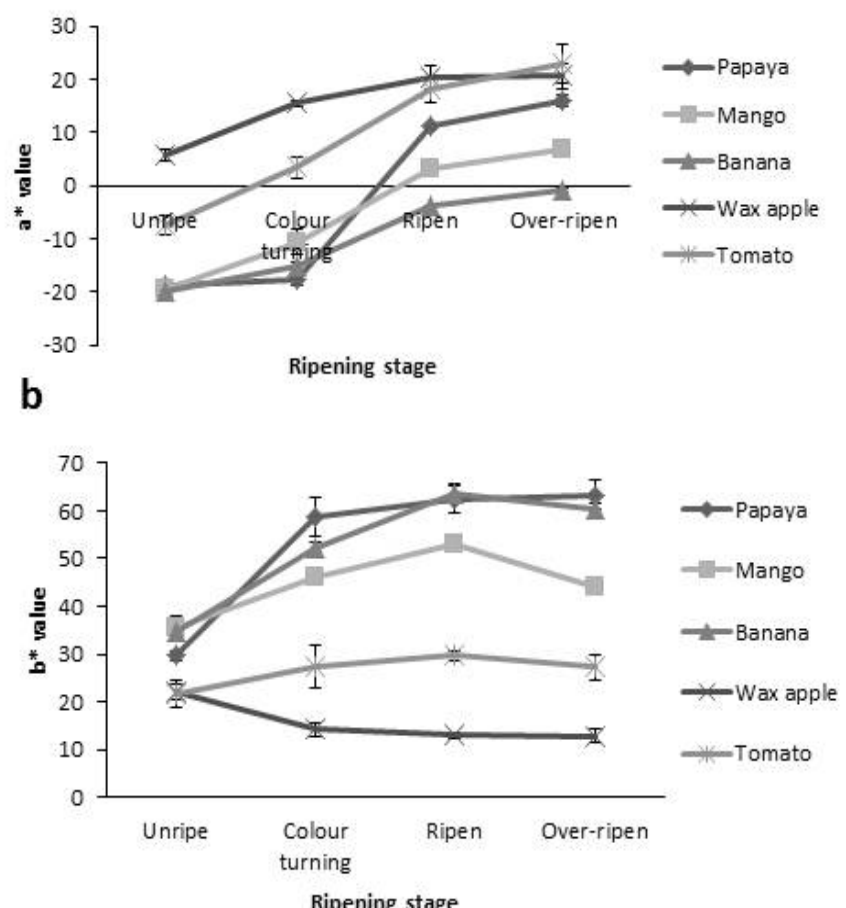

Fig 2. Peel colour components $a^{*}(a)$ and $b^{*}(b)$ in papaya, mango, banana, wax apple and tomato collected at different ripening stages. Each point is the mean $\pm S D$ of three replicates (fruits).

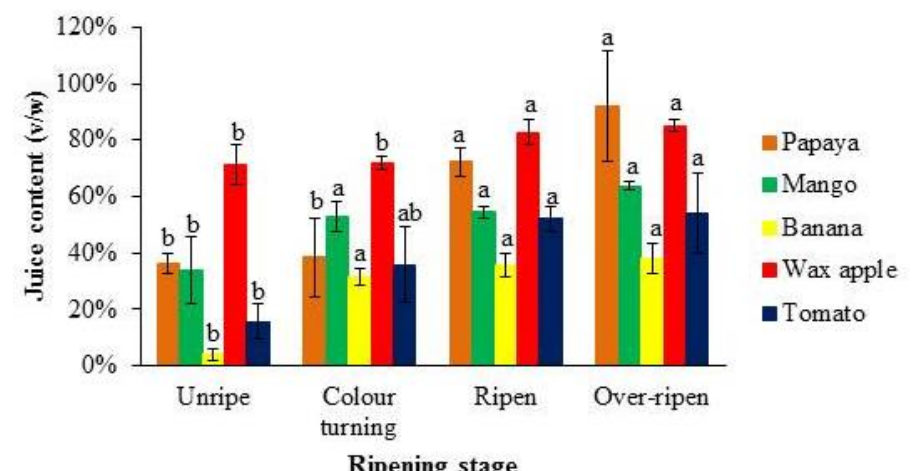

Fig 3. Juice content of papaya, mango, banana, wax apple and tomato samples at different ripening stage with the error bars (mean \pm SD).

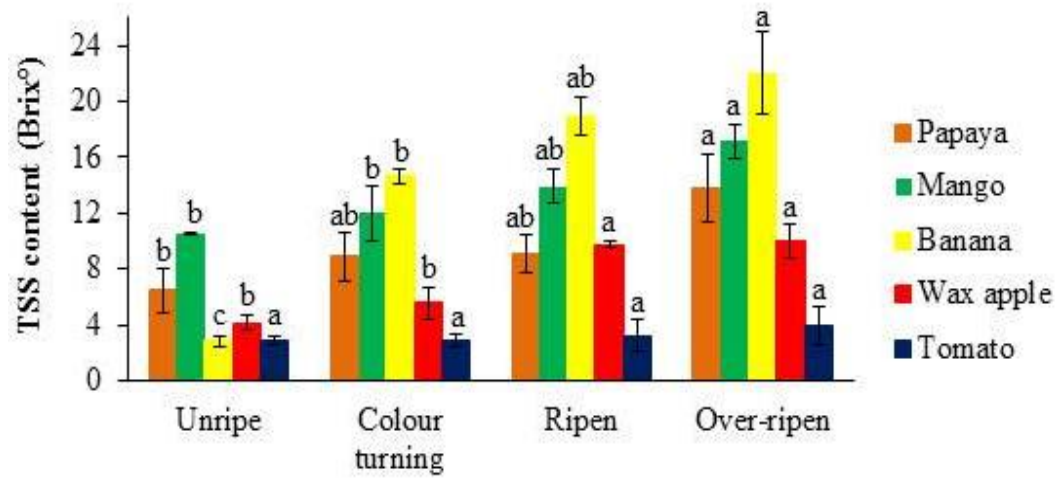

Ripening stage

Fig 4. Soluble solid content of papaya, mango, banana, wax apple and tomato samples at different ripening stage with the error bars (mean $\pm \mathrm{SD}$ ). 


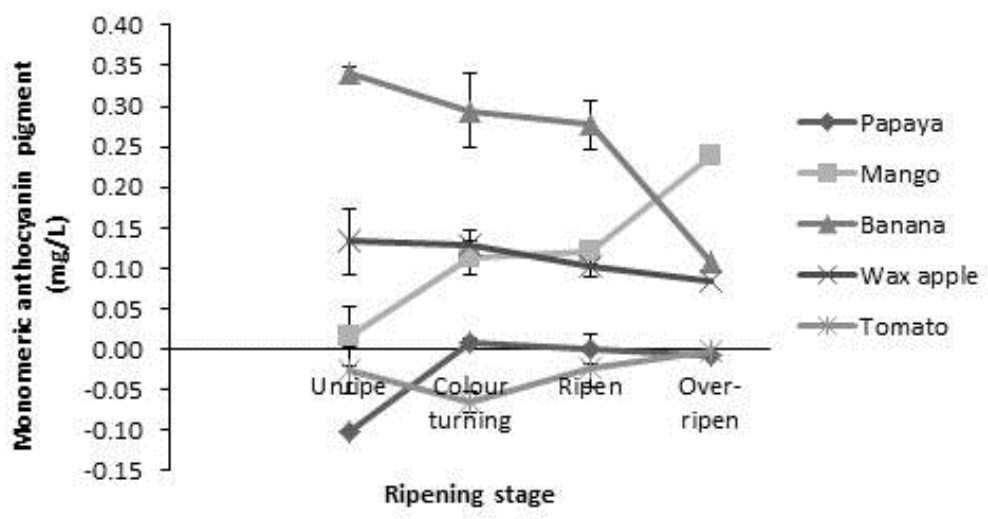

Fig 5. Total monomeric anthocyanin pigment of papaya, mango, banana, wax apple and tomato samples at different ripening stage with the error bars (mean $\pm S D$ ).

determined by lower saturation with high value of hue angle. Meanwhile, ripen fruit has higher saturation with low value of hue angle.

\section{Juice content}

The results of juice content in ripening stages of papaya, mango, banana, wax apple and tomato were presented in Figure 3 . The results showed significant differences $(P<0.05)$ between the ripening stages of papaya, mango, banana, wax apple and tomato. Based on Figure 3, papaya had shown the highest juice content compared to other fruits with a low amount of juice in unripe stage $(36.34 \mathrm{v} / \mathrm{w})$ and over-ripen stage $(92.29 \mathrm{v} / \mathrm{w})$. However, banana had shown the lowest juice content compared to other fruits with increasing of juice content from the lowest amount in unripe stage $(3.98 \mathrm{v} / \mathrm{w})$ and the highest amount in over-ripen stage $(37.96 \mathrm{v} / \mathrm{w})$.

Meanwhile in unripe stage of mango, it had shown the lowest juice content and increase with maturation that the showed highest juice content in over-ripen stage, in which can also be seen in wax apple and tomato. This had shown that in tomato, the juice content was affected by its maturity stage and can be contributed to different amount of juice at different maturity stage (Tilahun, 2013). However, juice content was also influenced by the fruit water content and its loss from the fruit (Jan et al., 2012). The best stage to consume fruit was at overripen stage as the juice content is the highest in all fruit. Meanwhile, papaya was the best fruit to consume as it contains the highest juice content compared to banana which has the lowest juice content.

\section{Total Soluble Solid (TSS)}

The result of TSS content in ripening stages of papaya, mango, banana, wax apple and tomato were presented in Figure 4 . The result showed significant differences $(P<0.05)$ between the ripening stages of papaya, mango, banana and wax apple. However, there was no significant difference $(P>0.05)$ in ripening stages of tomato.

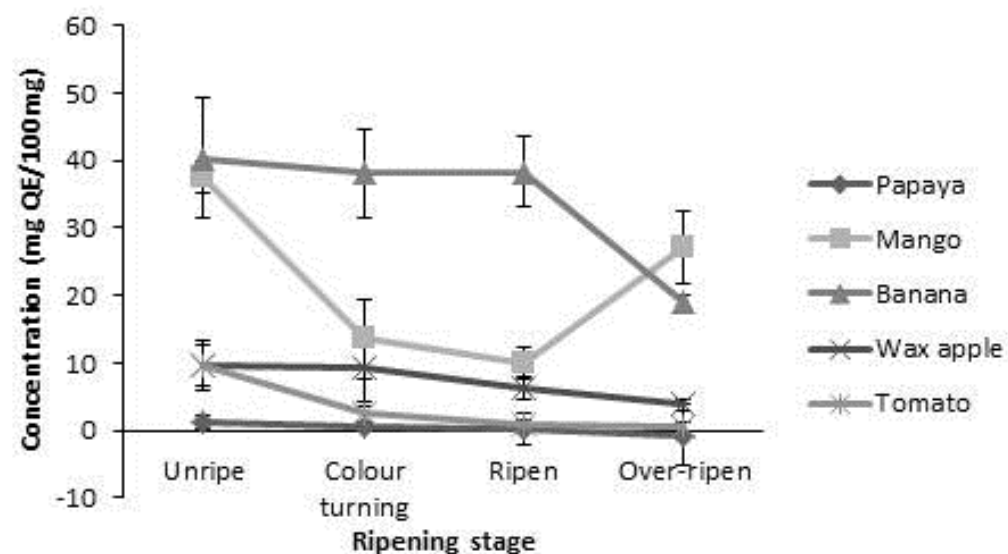

Fig 6. Flavonoid content in papaya, mango, banana, wax apple and tomato at different ripening stage in different concentrations with the error bars (mean $\pm \mathrm{SD}$ ).

Based on the Figure 4, banana had shown the highest TSS content compared to other fruits with the highest value in overripen stage ( $22^{\circ}$ Brix). According to Sandipkumar and

Shanmugasundaram (2015), fruit ripening in most fruits including banana causes starch hydolysis that result in sugar formation. Sugar content of plant parts affects their quality and storage life (Moneruzzaman et al., 2010b). Meanwhile, tomato had shown an increase in TSS content as the fruit matured but, showed no significant difference and possessed the lowest value $\left(2.9^{\circ}\right.$ Brix) as compared to other fruits. It had also been shown that mango and wax apple had significantly increased their of TSS contents as the fruit matured, with the lowest value in unripe stage and the highest value in over-ripen stage (Figure 4). The TSS content also increased significantly $(P<0.05)$ by the ripening process in papaya as reported in the study by Zuhair et al. (2013). The best stage to consume all fruits was at over-ripen 
stage as it contain the highest TSS content and banana was the best fruit to consume which has the highest TSS content as compared to tomato with the lowest TSS content.

\section{Total monomeric anthocyanin pigment}

Anthocyanin pigment content was found to be lower in tomato compared to other fruits with no significant difference $(P>$ 0.05). Meanwhile, banana had been shown to have the highest content of anthocyanin pigment as compared to other fruits with a significant decrease from high content at unripe stage at value of $0.341 \mathrm{mg} / \mathrm{L}$ to low content at over-ripen stage with value of $0.109 \mathrm{mg} / \mathrm{L}$ (Figure 5). The anthocyanin pigment in papaya showed a significant increase and decrease as the fruit matured, with low content in unripe stage with value of -0.102 $\mathrm{mg} / \mathrm{L}$ and high content in colour turning stage with value of $0.009 \mathrm{mg} / \mathrm{L}$.

Meanwhile, the anthocyanin pigment content in mango showed a significant increase with the highest value $(0.239 \mathrm{mg} / \mathrm{L})$ in over-ripen stage and the lowest value $(0.015 \mathrm{mg} / \mathrm{L})$ in unripe stage (Figure 5). Anthocyanin pigment in wax apple had shown no significant difference $(P>0.05)$ with the lowest value in overripen stage $(0.083 \mathrm{mg} / \mathrm{L})$ and the highest value in unripe stage $(0.134 \mathrm{mg} / \mathrm{L})$. Khandaker et al. (2011) reported that anthocyanin content correlated with peel colour of wax apple in girdle fruits. The anthocyanin pigment accumulation is correlates with peel colour changes as reported by Pedisic et al. (2010), that indicates high anthocyanin content in darker colour of sour cherry cultivar. The best stage to consume fruit is when the matured fruit ripen as it contains high anthocyanin pigment compared with immature fruit. Banana was the best fruit to consume as it has the highest anthocyanin content as compared to tomato which has the lowest anthocyanin content.

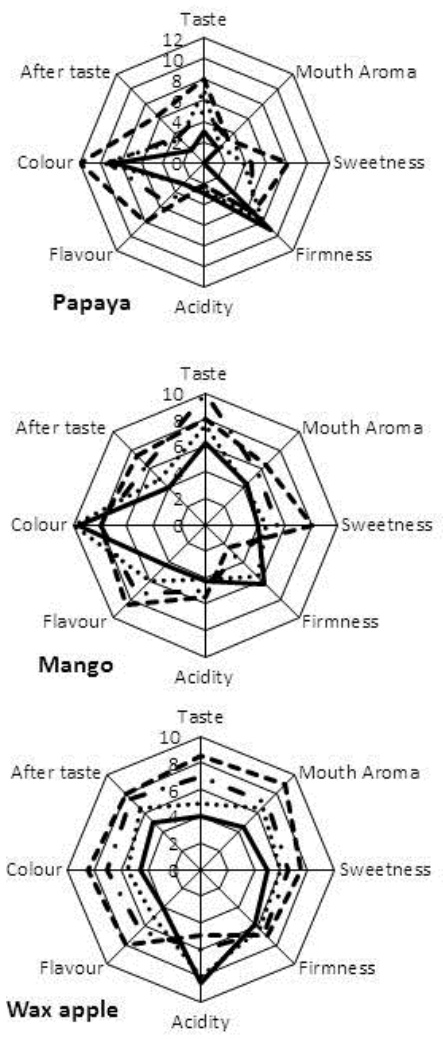

\section{Total flavonoid content (TFC)}

Flavonoid content was found to be lower in papaya than other fruit with values between -0.69 to $1.27 \mathrm{mg} \mathrm{QE} / 100 \mathrm{~g}$ (Figure 6). However, the papaya is not significantly different $(P>0.05)$ against the ripening stage in which there are not much changes of flavonoid content during the ripening process. Figure 6 shows the flavonoid content of banana was significantly higher than other fruits which was between 18.96 to $40.37 \mathrm{mg}$ QE/100 g.

The flavonoid content in wax apple and tomato had been shown to be lower in over-ripen stage with values of 3.77 and $0.37 \mathrm{mg}$ $\mathrm{QE} / 100 \mathrm{~g}$, respectively, and higher in unripe stage with values 9.73 and $9.60 \mathrm{mg} \mathrm{QE} / 100 \mathrm{~g}$, respectively. However, mango had shown a decrease in flavonoid content from unripe stage to ripen stage but significantly increased from ripen stage to overripen stage (Figure 6). The flavonoid is a natural pigment that can naturally be found in plant in which it can be affected by the fruit peel colouration (Schmidt et al., 2015). The best stage to consume fruit is when the fruit is immature to get high flavonoid intake. Our results also showed that banana was the best fruit to consume because it has the highest flavonoid content at ripen stage compared to papaya which had the lowest flavonoid content. Haq et al. (2011) reported that different varieties produce different amounts of natural product and their bioactivities were also different.

There were significantly positive relationships between the juice and TSS content of wax apple, banana, mango and papaya fruits (Table 2). Juice and TSS content increased simultaneously with the advanced ripening.
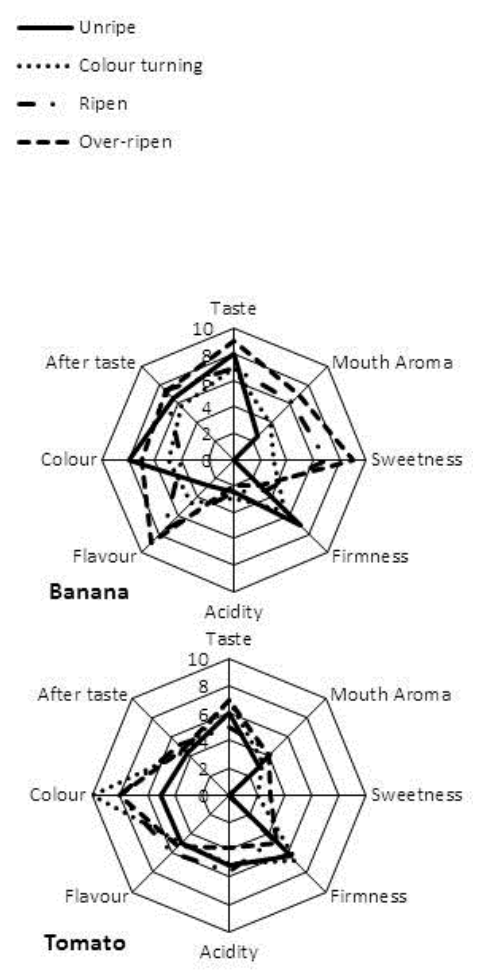

Fig 7. Taste panel scoring of some common fruits at different ripening stages based on examined quality attributes. Twelve panelists were evaluated randomly offered fruits on a scale 0 for the lowest and 10 for the highest score based on the taste, flavor, colour, firmness, acidity, sweetness, mouth aroma, and taste remaining after swallowing quality criteria. 
The regression equation showed that TSS content was the highest in wax apple fruits while juice content was the highest $(r=0.97)$. The findings of this study were supported by Moneruzzaman et al. (2011), who reported that juice and TSS content of Jambu Madu Red cultivar of wax apple correlates positively. Similarly, a significant strong positive correlation was also observed in mango fruits, and the highest contents of juice and TSS were recorded in the yellowish-red ripen stage. The results also showed that anthocyanin content of mango fruits strongly correlated positively $(r=0.96)$ with TSS content (Table 2). This positive correlation suggests that fruit with higher TSS content is also an indicator of higher anthocyanin content, which represents the better quality. Besides, anthocyanin content was not strongly correlated $(r=0.21)$ with the TSS content of wax apple fruits (Table 2).

\section{Taste panel evaluation}

The attributes of colour, flavour, taste, after taste, sweetness, firmness, mouth aroma and acidity of different maturity stages fruit samples were determined by the taste panel scoring (Figure 7). The panelist had given the highest score of sweetness for banana as compared to other fruits as it is in agreement with TSS content in Figure 4 that showed the highest ${ }^{\circ}$ Brix in banana. The high sweetness can also be correlated with low score on acidity. Mouth aroma scoring was high in wax apple as the fruit ripen (Figure 7). According to Lalel et al. (2003), aroma volatile compound had increased as the mango ripens. Overall score showed the best scoring of attributes was from the over-ripen stage of all fruit types. This indicates the best stage to consume fruit was at ripen stage. It has been also reported that fruit quality can be changed by applying different plant growth regulators (Khandaker et al., 2012).

Thus, the best fruit quality to consume based on sensory evaluation was banana as it obtained the highest in the attributes of sweetness, flavour and colour compared with other fruits. The best stage of fruit to consume according to sensory attributes score was when the fruit is ripen to over ripen.

\section{Materials and Methods}

\section{Sample collection}

Local fruit of five different types, papaya (Carica papaya L. var Eksotika), mango (Mangifera Indica L. var. Arumanis), banana (Musa acuminata var. Pisang emas), wax apple (Syzygium samarangense var. Jambu madu) and tomato (Solanum lycopersicum var. MT1) was collected from markets at various locations in Besut, Terengganu. The collected fruit was chosen based on their ripening stages by their peel colour. All the five fruits were collected at unripe, colour turning, ripen and overripen stages. We have chosen these fruits because all are locally grown produce and available in the local market. All five fruits were available at different ripening stages in the local market but consumers are not sure at which stages these fruits contain the better quality.

\section{Peel colour analysis}

The peel colour of the fruits was measured using the device of Minolta colorimeter (CR-300, Konica, Japan) using the methodology by Tehrani et al. (2011). Parameters such as "L" (lightness), "a" (greenness to redness) and "b" (blueness to yellowness) were determined at three different parts of fruit (top, bottom and middle portion). Sample averages were calculated and the colour was expressed in $L * a *$, and $b *$ Hunter parameters. By using the parameters, Chroma value, $\Delta C$ and hue angle, $h^{\circ}$ was calculated using the following formula:

Chroma value, $\Delta C=\sqrt{a^{* 2}+b^{* 2}}$

Hue angle, $h^{\circ}=\tan ^{-1} \frac{b^{*}}{a^{*}}$

\section{Determination of Juice and TSS content}

The fresh fruit collected was extracted and weighed. The average juice weigh was calculated separately by each fruit sample. The collected fruit juice was weighed by using electronic balance. The average fruit juice was obtained by the following formula

$$
\text { Percentage juice }=\frac{\text { Juice weight per fruit }}{\text { Fruit weight }} \times 100
$$

The fruit juice that had been extracted from the collected fruits was used. The total soluble solids (TSS) value of fruit juices were evaluated at $25{ }^{\circ} \mathrm{C}$ with an Atago 8469 hand refractometer (Atago Co. Ltd., Tokyo, Japan) and expressed as ${ }^{\circ}$ Brix. Several readings were taken and the samples average had been calculated.

\section{Determination of total anthocyanin and flavonoids content}

Total anthocyanin content of the fruit extract was determined by differential $\mathrm{pH}$ method (Rodriguez-Saona et al., 1999). Samples was diluted by the ratio of $1: 4$ with two different $\mathrm{pH}$ buffer solutions: $0.025 \mathrm{M}$ potassium chloride, $\mathrm{pH} 1.0$; and $0.4 \mathrm{M}$ sodium acetate, $\mathrm{pH}$ 4.5. The $\mathrm{pH}$ was adjusted using concentrated hydrochloric acid. The samples was measured with absorbance at $530 \mathrm{~nm}$ and $700 \mathrm{~nm}$ wavelengths by using water as the blank. The different of absorbance between $\mathrm{pH} 1.0$ and $\mathrm{pH} 4.5$ samples was calculated as follows:

$A=\left(A_{530 n m}-A_{700 n m}\right)_{p H 1.0}-\left(A_{530 n m}-A_{700 n m}\right)_{p H 4.5}$

The monomeric anthocyanin pigment concentration was calculated using the following formula:

Monomeric anthocyanin pigment $(\mathrm{mg} / \mathrm{L})=(\mathrm{A} \times \mathrm{MW} \times \mathrm{DF} \times 1000) /(\varepsilon \times 1)$ $\mathrm{MW}=449.2, \varepsilon=26,900$ and $\mathrm{DF}=$ Dilution factor

Total flavonoids content was measured using method by Zhishen et al. (1999). An aliquot ( $1 \mathrm{~mL}$ ) of the sample extracts or a standard solution of quercetin $(20,40,60,80$ and $100 \mathrm{mg} / \mathrm{L})$ was added to distilled water in $10 \mathrm{~mL}$ volumetric flasks containing $4 \mathrm{~mL}$ of distilled water. Next, $0.3 \mathrm{~mL} 5 \% \mathrm{NaNO}_{2}$ was added to the flask. Then, $0.3 \mathrm{~mL} 10 \% \mathrm{AlCl}_{3}$ was added after 5 min. After one minute, $2 \mathrm{~mL}$ of $1 \mathrm{M} \mathrm{NaOH}$ was added and the total volume was made up to $10 \mathrm{~mL}$ with distilled water. The solution was mixed well and the absorbance was measured against a blank sample at $510 \mathrm{~nm}$. The total flavonoid content of fresh fruit was expressed as mg quercetin equivalents (QE)/100 $\mathrm{g}$ fresh mass. Samples were analyzed in average of three replicates.

\section{Taste panel evaluation}

To evaluate the overall sensory characteristics of the five types of fruits; papaya, mango, banana, wax apple and tomato from different maturity stages and a taste panel was conducted with twelve panelists. They evaluated the randomly offered fruits on a scale from 0 to 10 (low-high scores for each evaluated variable) based on the following criteria: taste, flavour, colour, firmness, acidity, sweetness, mouth aroma, and taste that remains after swallowing.

\section{Data analysis}

The results in this experiment of triplicate were expressed as mean \pm standard deviation. The data had been analysed using 
Microsoft Excel software. Statistical analysis was done using Minitab 16 software using one way repeated ANOVA to determine the significance among the maturity stages of the five different local fruit samples and the value of $p>0.05$ was considered as significant.

\section{Conclusion}

As a conclusion, the $L^{*}, a^{*}$ and $b^{*}$ values as well as chroma value and hue angle was used to identify the ripening stage of fruit. The highest juice content was recorded in papaya while the lowest juice content was found in banana. The TSS content of banana was the highest compared to tomato which has the lowest TSS content. The anthocyanin and flavonoid contents were the highest in banana compared to other fruits. Meanwhile, tomato has the lowest anthocyanin content and papaya has the lowest flavonoid content than other fruits. Juice, TSS and anthocyanin content of fruits increase with advanced ripening and significant positive correlations were recorded in mango and banana fruits. As for the sensory evaluation, banana and mango scores the highest in all attributes while tomato scores the lowest for fresh consumption.

\section{Acknowledgement}

We greatly thank the Research Management, Innovation \& Commercialization Centre (RMIC), Universiti Sultan Zainal Abidin (UniSZA), Terengganu, Malaysia for giving support in the publication of this research.

\section{References}

Abbott JA (1999) Quality measurement of fruits and vegetables. Postharvest Biol Technol. 15: 207-225.

Al-Saif AM, Sharif Hossain ABM, Taha RM, Moneruzzaman KM (2011) Photosynthetic yield, fruit ripening and quality characteristics of cultivars of Syzygium samarangense. Afr J Agril Res. 6 (15): 3623-3630.

Ayala-Silva T, Schnell RJ, Meereow AW, Winterstein M, Cervantes C, Brown JS (2005) Determination of color and fruit traits of half-sib families of mango (Mangifera Indica L.). Proc Fla State Hort Soc. 118: 253-257.

Basulto FS, Duch ES, Gil FE, Plaza RD, Saavedra AL, Santamaría JM (2009) Postharvest ripening and maturity indices for Maradol papaya. Interciencia. 34: 583-588.

Haq I, Wirakarnain S, Shariff Hossain ABM, Rosna MT, Moneruzzaman KM (2011) Total phenolic contents, antioxidant and antimicrobial activities of Bruguiera gymnorrhiza. J Med Plants Res. 5 (17): 4112-4118.

Jan I, Rab A, Sajid M (2012) Storage performance of apple cultivars harvested at different stages of maturity. J Anim Plant Sci. 22(2): 438-44.

Kamol S, Howlader J, Sutra Dhar G, MA (2014) Effect of different stages of maturity and postharvest treatments on quality and storability of pineapple. J Bangladesh Agril Univ. 8: 251-260.

Khandaker MM, Hossain AS, Osman N, Boyce AN (2011) Application of girdling for improved fruit retention, yield and fruit quality in Syzygium samarangense under field conditions. Int J Agric Biol. 13: 18-24.

Khandaker MM, Boyce AN, Normaniza O, Hossain ABMS (2012) Physiochemical and phytochemical properties of wax apple (Syzygium samarangense [Blume] Merrill \& L.M. Perry) as affected by growth regulator application under field conditions. Sci World J. 2012, Article ID 728613.

Lalel H, Zora SS, Tan C (2003) The role of ethylene in mango fruit aroma volatile biosynthesis. J Hort Sci Biotechnol. 78(4):485496.
Moneruzzaman KM, Hossain ABMS, Sani W, Saifuddin M (2008) Effect of stages of maturity and ripening conditions on the physical characteristics of tomato. Amer J Biochem Biotechnol. 4 (4): 329-335.

Moneruzzaman KM, Boyce AN, Normaniza O, Faruq G, Motior Rahman M, Sofian-Azirun M (2013) Fruit development, pigmentation and biochemical properties of wax apple as affected by localized application of $\mathrm{GA}_{3}$. Braz Ach Biol Technol. 56(1):11-20.

Moneruzzaman KM, Hossain ABMS, Normaniza O, Saifudin M, Sani W, Amru NB (2010a) Effects of removal of young leaves and cytokinin on inflorescence development and bract enlargement in Bougainvillea glabra var. "Elizabeth Angus". Aus J Crop Sci. 4 (7): 467-473.

Moneruzzaman KM, Hossain ABMS, Saifuddin M, Imdadul $H$, Normaniza O, Amru NB (2010b) Effects of sucrose and kinetin on the quality and vase life of Bougainvillea glabra Var. Elizabeth angus bracts at different temperature. Aus J Crop Sci. 4(7): 474-479.

Moneruzzaman KM, Al-Saif AM, Alebedi Al, Hossain ABMS, Normaniza O, Nasrulhaq Boyce A (2011) Nutritional quality evaluation of three cultivars of Syzygium samaragense under Malaysian conditions. Afr J Agril Res. 6 (3):545-552.

Pedisic S, Dragovic-Uzelac V, Levaj B, Skevin D (2010) Effect of maturity and geographical region on anthocyanin content of sour cherries (Prunus cerasus var. marasca). Food Technol Biotechnol. 48(1): 86-93.

Rodriguez-Saona L, Giusti M, Wrostland R (1999) Color and pigment stability of red radish and red-fleshed potato anthocyanins in juice model systems. J Food Sci. (64): 451-456.

Rosnah S, Wong WK, Noraziah M, Osman H (2012) Chemical composition changes of two water apple (Syzygium samaragense). Int Food Res J 19(1):167-174.

Saifuddin M, Hossain ABMS, Normaniza O, Nasrulhaq Boyce A, Moneruzzaman KM (2009) The effects of naphthalene acetic acid and gibberellic acid in prolonging bract longevity and delaying discoloration of Bougainvillea spectabilis. Biotechnol. 8(3):343-350.

Sandipkumar SP, Shanmugasundaram S (2015) Physicochemical Changes During Ripening of Monthan Banana. Int J Technol Enhanc Emerg Eng Res. 3(02): 18-21.

Schmidt M, Prestes R, Kubota E, Scapin G, Mazutti M (2015) Evaluation of antioxidant activity of extracts of banana inflorescences (Musa cavendishii). CyTA - J Food, 13(4): 498505.

Sudheer K, Indira V (2007) Post harvest technology of hortciultural crops; maturity and harvesting. New Delhi: New India Publishing Agency.

Tilahun AT (2013) Analysis of the effect of maturiy stage on the postharvest biochemical quality characteristics of tomato (Lycopersicon esculentum MILL.) Fruit. Int Res J Pharm App Sci. 3(5): 180-186.

Tehrani M, Sharif Hossain ABM, Nasrulhaq-Boyce A (2011) Postharvest physico-chemical and mechanical changes in'Jambu Air'(Syzygium aqueum Alston) fruits. Aus J Crop Sci. 5(1):32-38.

Zhishen J, Mengchen T, Jiaming W (1999) The determination of flavonoid contents in mulberry and their scavenging effects on superoxide radicals. Food Chem. (64): 555-559.

Zuhair RA, Aminah A, Sahilah AM, Eqbal D (2013) Antioxidant activity and physicochemical properties changes of papaya (Carica papaya L. Cv. Hongkong) during different ripening stage. Int Food Res J. 20(4):1653-1659. 